\title{
Effects of a dietary organic acid mixture and of dietary fibre levels on ileal and faecal nutrient apparent digestibility, bacterial nitrogen flow, microbial metabolite concentrations and rate of passage in the digestive tract of pigs
}

\author{
K. Partanen ${ }^{1 \dagger}$, T. Jalava ${ }^{2}$ and J. Valaja ${ }^{2}$ \\ ${ }^{1}$ MTT Agrifood Research Finland, Animal Production Research, Tervamäentie 179, Fl-05840 Hyvinkää, Finland; ${ }^{2}$ MTT Agrifood Research Finland, Animal Production \\ Research, Fl-31600 Jokioinen, Finland
}

(Received 27 June 2006; Accepted 13 November 2006)

Six 34-kg barrows were fitted with a post-valve T-caecum cannula and assigned to six dietary treatments according to a $6 \times 5$ change-over design to study how a mixture of formic acid, sorbate, and benzoate $(0$ or $8.4 \mathrm{~g} / \mathrm{kg}$ feed) influences apparent ileal and faecal digestibility coefficients, bacterial nitrogen (N) flow, microbial metabolite concentrations, and passage rate in pigs fed isoenergetic diets with medium, high, or very high fibre content (neutral-detergent fibre (NDF): 199, 224, and $248 \mathrm{~g} / \mathrm{kg}$ dry matter, respectively). These barley and soya-bean meal based diets contained 0, 75, and $150 \mathrm{~g} / \mathrm{kg}$ barley fibre (NDF: $577 \mathrm{~g} / \mathrm{kg}$ ) and 0, 8, and $16 \mathrm{~g} / \mathrm{kg}$ rapeseed oil, respectively. The dietary organic acid mixture improved the apparent ileal digestibility of 14 of the 17 amino acids analysed $(\mathrm{P}<0.05)$. Increasing levels of dietary fibre linearly decreased the apparent ileal digestibility of six of the 17 amino acids analysed $(\mathrm{P}<0.05)$. Ileal flows of bacterial $N$ and amino acids as assessed on the basis of purine flow were decreased by the dietary organic acid mixture $(\mathrm{P}<0.05)$ but were not affected by dietary fibre level $(\mathrm{P}>0.05)$. As assessed on the basis of diaminopimelic acid flow, bacterial $N$ flow was increased by both the dietary organic acid mixture and increased dietary fibre levels $(\mathrm{P}<0.05)$. The dietary organic acid mixture reduced the concentration of lactic acid and increased that of acetic acid in ileal digesta $(\mathrm{P}<0.05)$, while dietary fibre levels had a quadratic effect on concentrations of acetic, propionic, and butyric acid ( $\mathrm{P}<0.05)$. The mean retention time of $\mathrm{Co}$ (solute marker) and $\mathrm{Yb}$ (particle marker) in the large intestine decreased in a linear manner by increasing dietary fibre levels $(\mathrm{P}<0.05)$ but was not affected by the dietary organic acid mixture $(\mathrm{P}>0.05)$. The results show that a dietary organic acid mixture has a positive effect on the apparent ileal digestibility of most amino acids irrespective of dietary fibre levels. This could be at least partly related to changes in bacterial $\mathrm{N}$ flow in the ileum. However, different bacterial markers showed opposite effects on bacterial $N$ flow, which makes it questionable to use a constant bacterial marker / bacterial $N$ ratio to estimate bacterial $N$ flow. Increasing levels of dietary fibre had negative effects on the apparent ileal amino acid digestibilities and shortened the mean retention time of digesta in the large intestine.

Keywords: bacterial protein, digestibility, organic acids, pigs, retention time

\section{Introduction}

Dietary acidification with organic acids has been shown to improve the growth and feed-to-gain ratio of weaned piglets and growing-finishing pigs, but the mechanisms whereby dietary organic acids enhance pig performance are still poorly understood (Ravindran and Kornegay, 1993; Partanen and Mroz, 1999). Several studies have demonstrated that dietary organic acids improve the ileal apparent digestibility of protein and amino acids in

\footnotetext{
${ }^{\dagger}$ E-mail: kirsi.partanen@mtt.fi
}

growing-finishing pigs (Mosenthin et al., 1992; Kemme et al., 1999; Mroz et al., 2000; Partanen et al., 2001). A common hypothesis has been that dietary acidification improves protein digestibility by lowering gastric $\mathrm{pH}$, which consequently increases pepsin activity. This should, in theory, improve both the ileal apparent and true digestibility of amino acids. However, dietary formic acid did not affect the true ileal digestibility of lysine in soya-bean meal as determined with the homoarginine technique, although the ileal apparent digestibility of dietary lysine was improved (Partanen et al., 2001). 
Ileal digesta contain considerable amounts of protein and amino acids from various endogenous secretions and protein synthesised by microbes of the digestive tract. The estimated amounts of bacterial nitrogen (N) in ileal digesta have ranged greatly from 0.14 up to 0.74 of total ileal $\mathrm{N}$ (Wünsche et al., 1991; Schulze et al., 1994; Bartelt et al., 1999; Huang et al., 2001). Because organic acids are antimicrobial agents, their effects on ileal apparent amino acid digestibilities can be mediated via microbes of the digestive tract. Several authors have reported changes in bacterial counts and microbial metabolite concentrations in gastric and intestinal digesta of pigs fed diets supplemented with formic acid (Roth et al., 1992; Canibe et al., 2005). Reduced bacterial protein synthesis may contribute to the improved ileal apparent protein and amino acid digestibilities seen with the diets supplemented with organic acids (Partanen et al., 2001).

The length of time that digesta remain in the digestive tract of the pig and are exposed to digestive enzymes and microbial degradation largely influences the extent to which the feeds are digested. In general, highly soluble dietary fibres such as pectins reduce the rate of passage in the stomach and small intestine of pigs, while cellulose and insoluble lignified dietary fibre reduces transit time in the lower part of the digestive tract (Wenk, 2001). Ravindran and Kornegay (1993) suggested that dietary acidification may reduce the gastric emptying rate, but the effect of dietary organic acid supplementation on the passage rate of digesta through the digestive tract of pigs has not been investigated so far.

The objective of this study was to determine how an organic acid mixture based on formic acid used in diets with increasing fibre content levels influences the ileal and faecal apparent digestibility of nutrients, particularly amino acids, and bacterial $\mathrm{N}$ flow, microbial metabolite concentrations in the ileum, and the rate of passage in the upper and lower part of the digestive tract of pigs.

\section{Material and methods}

The experimental protocol was reviewed and approved by the Animal Care Committee of MTT Agrifood Research Finland.

\section{Animals and surgery}

Seven 34-kg barrows (Yorkshire $\times$ Finnish Landrace) were surgically fitted with a T-shaped silicone cannula at the caecum according to the post-valve T-caecum (PVTC) cannulation method (Van Leeuwen et al., 1991). Before surgery, the pigs were fasted for $36 \mathrm{~h}$ and given no access to water for $12 \mathrm{~h}$. After pre-medication with Stresnil $(8 \mathrm{mg} / \mathrm{kg}$ i.m., Orion, Finland) and atropine $(0.05 \mathrm{mg} / \mathrm{kg}$ i.m., Leiras, Finland), anaesthesia was induced by i.v. injection of pentothal (Natrium Abbott) and maintained by inhalation of halothane (1 to $4 \%$ as necessary). To minimise pain, the pigs were injected with Finadyne $(2.2 \mathrm{mg} / \mathrm{kg}$ i.m., Orion,
Finland) immediately after surgery, after which they were given Finadyne $(250 \mathrm{mg} /$ day, Orion, Finland) with feed for 3 days. To prevent infections, the pigs were injected with Tribrissen ( $20 \mathrm{mg} / \mathrm{kg}$ i.m., Pitman-Moore $\mathrm{GmbH}$, Germany) immediately after surgery, after which they were given Oriprim ( $10 \mathrm{~g} /$ day, Orion, Finland) with feed for 7 days. The pigs were allowed a 16-day recovery period, during which their daily allowance was gradually increased until the presurgical level of feed intake was achieved. Access to water was ad libitum. The pigs were housed in metabolic pens measuring $1.43 \mathrm{~m} \times 1.23 \mathrm{~m}$ with a slatted plastic floor and transparent plastic sides at an ambient temperature of 20 to $23^{\circ} \mathrm{C}$.

\section{Experimental diets}

The medium-fibre diet was based on barley and soya-bean meal. High-fibre and very-high-fibre diets were obtained by including 75 and $150 \mathrm{~g} / \mathrm{kg}$ respectively of barley fibre (Tähkä-Ohrarehu 12, Altia Ltd, Koskenkorva, Finland) from integrated starch-ethanol production in the diet based on barley and soya-bean meal. Per $\mathrm{kg}$, the barley fibre used contained $39 \mathrm{~g}$ ash, $121 \mathrm{~g}$ crude protein, $68 \mathrm{~g}$ crude fat, $183 \mathrm{~g}$ crude fibre, $577 \mathrm{~g}$ neutral-detergent fibre (NDF), $209 \mathrm{~g}$ acid-detergent fibre (ADF), and $31 \mathrm{~g}$ lignin. The diets were formulated to be isoenergetic by adding rapeseed oil in the high-fibre and very-high-fibre diets. The diets supplied $9.2 \mathrm{MJ}$ of net energy and $6.9 \mathrm{~g}$ of ileal apparent digestible lysine per $\mathrm{kg}$. The nutrient contents of the experimental diets were calculated by using tabulated values for different feed ingredients (Tuori et al., 1996). Vitamins and minerals were supplemented to meet or exceed Finnish feeding recommendations according to Tuori et al. (1996). For the determination of digestibility coefficients, chromium-mordanted straw prepared according to Udén et al. (1980) was added to feeds $(1.6 \mathrm{~g} / \mathrm{kg})$ as an indigestible marker. The formulations of medium-fibre, high-fibre, and very-high-fibre diets are given in Table 1. These diets were prepared either with or without an organic acid mixture that contained 94\% formic acid (BOLIFOR FA 1100L, 76\% formic acid, $5.5 \%$ ammonium formate, and $18.5 \%$ water (v/w); Kemira Chemicals Ltd, Finland), 3\% potassium sorbate, and 3\% sodium benzoate. This mixture was chosen based on preliminary information from an in vitro study which indicated that small amounts of potassium sorbate or sodium benzoate in formic acid could result in greater changes in fermentation patterns in the small intestine than plain formic acid (Partanen and Jalava, 2005). The acid mixture provided $6.1 \mathrm{~g}$ formic acid, $0.4 \mathrm{~g}$ ammonium formate, $0.2 \mathrm{~g}$ potassium sorbate, and $0.2 \mathrm{~g}$ sodium benzoate per $\mathrm{kg}$ of feed. The diets were pelleted through 4-mm die (Amandus Kahl Nache, Germany) without using steam.

\section{Experimental procedures}

The experiment was carried out with six pigs according to a $6 \times 5$ cyclic change-over design (Davis and Hall, 1969). There were five 14-day experimental periods, and each pig received a different diet in each period. The pigs were 
Table 1 Ingredients and calculated composition of experimental diets with different amounts of fibre ${ }^{\dagger}$

\begin{tabular}{lccc}
\hline \hline & \multicolumn{3}{c}{ Fibre content } \\
\cline { 2 - 4 } & Medium & High & Very high \\
\hline Ingredients (g/kg) & & & \\
Barley & 830.3 & 743.2 & 653.9 \\
Barley fibre & - & 74.9 & 149.8 \\
Soya-bean meal & 142.2 & 146.8 & 152.7 \\
Rapeseed oil & - & 7.7 & 16.4 \\
Mineral and vitamin pre-mix ${ }^{\ddagger}$ & 13.0 & 13.0 & 13.0 \\
Limestone & 7.7 & 7.7 & 7.7 \\
Monocalcium phosphate & 3.9 & 3.8 & 3.7 \\
L-lysine HCl & 1.3 & 1.3 & 1.2 \\
Chromium mordanted straw & 1.6 & 1.6 & 1.6 \\
Calculated composition & & & \\
Net energy (MJ/kg) & 9.2 & 9.2 & 9.2 \\
Crude protein (g/kg) & 158 & 158 & 159 \\
lleal apparent digestible amino acids (g/kg) & & \\
Lysine & 6.9 & 6.9 & 6.9 \\
Methionine and cystine & 4.3 & 4.3 & 4.3 \\
Threonine & 4.2 & 4.2 & 4.2 \\
Calcium (g/kg) & 6.9 & 6.9 & 6.9 \\
Phosphorus (g/kg) & 5.2 & 5.2 & 5.2 \\
\hline \hline
\end{tabular}

${ }^{\dagger}$ Diets were prepared either with or without $8.4 \mathrm{~g} / \mathrm{kg}$ of an organic acid mixture that provided $6.4 \mathrm{~g}$ formic acid, $0.4 \mathrm{~g}$ ammonium formate, $0.2 \mathrm{~g}$ potassium sorbate, and $0.2 \mathrm{~g}$ sodium benzoate per $\mathrm{kg}$ of feed.

${ }^{\ddagger}$ The pre-mix supplied $(\mathrm{g} / \mathrm{kg})$ : calcium, 2.3; phosphorus, 0.8; magnesium, 0.5; sodium chloride, 3.3; (mg/kg) iron, 103; copper, 22; zinc, 91; manganese, 23; selenium, 0.28 ; iodine, 0.28 ; retinol, $1.6 ; \alpha$-tocopherol, $50 \mathrm{mg}$; thiamine, 2 ; riboflavin, 5; pyridoxine, 3; biotin, 0.2 ; pantothenic acid, 14; nicotinic acid, 20; folic acid, 2; menadione, 2; ( $\mu \mathrm{g} / \mathrm{kg})$ cholecalciferol, 13; and cyanocobalmin, 20.

weighed at the beginning of each period. All pigs were given the same amount of feed, i.e. $100 \mathrm{~g}$ per $\mathrm{kg}$ of mean metabolic body weight $\left(\mathrm{M}^{0.75}\right)$ of the pigs. The feed allowance was kept constant for the whole 14-day experimental period. The pigs were fed twice daily, at 0600 and $1800 \mathrm{~h}$. Feed was mixed with water ( $2 \mathrm{l} / \mathrm{kg}$ feed) before feeding. The pigs consumed their meals rapidly, generally in less than 30 min.

Each experimental period was started with six days of adaptation. At $1200 \mathrm{~h}$ on day 7, ca 100-ml spot samples were taken from ileal digesta for the determination of $\mathrm{pH}$, microbial metabolites, and microbial activity (ATP concentration). The chosen sampling time was based on the results of our previous study (Partanen et al., 2001). Samples for the determination of microbial metabolite concentrations were prepared as described by Partanen et al. (2001) and stored at $-18^{\circ} \mathrm{C}$ until analysed. For the determination of ATP concentration, $5 \mathrm{~g}$ of freshly collected digesta were mixed with $10 \mathrm{ml}$ of cold PCA-EDTA solution ( $2 \mathrm{~mol} / \mathrm{l}$ perchloric acid with $10 \mathrm{mmol} / \mathrm{l}$ EDTA) and frozen immediately at $-80^{\circ} \mathrm{C}$ until analysed.

The rate of passage was determined by means of a single pulse dose using cobalt $(\mathrm{Co})$ and ytterbium $(\mathrm{Yb})$ as solute and particle markers, respectively. During the feeding at $0600 \mathrm{~h}$ on day 8 , the pigs received $27 \mathrm{~g}$ of
Yb-labelled barley fibre (7.5 mg of $\mathrm{Yb}$ per g) prepared according to Beauchemin and Buchanan-Smith (1989) and $20 \mathrm{ml}$ of lithium-Co-EDTA solution ( $3.4 \mathrm{mg}$ of Co per $\mathrm{ml}$ ) prepared according to Udén et al. (1980) per $\mathrm{kg}$ of feed. Spot samples of ileal digesta consisting of about $50 \mathrm{ml}$ were collected $1,2,3,4,5,6,7,8,9,10,11,12,14,16$, $18,20,22,24$, and $30 \mathrm{~h}$ after dosing the markers. Faeces were collected quantitatively from $0600 \mathrm{~h}$ on day 8 to $0600 \mathrm{~h}$ on day 12 for the total of $96 \mathrm{~h}$ according to Van Kleef et al. (1994). The faecal bags were emptied 6, 12, $18,24,28,32,36,40,48,54,60,72,84$, and $96 \mathrm{~h}$ after dosing the markers. All faeces passed between emptying times were pooled, mixed, and subsampled for the analysis of $\mathrm{Co}$ and $\mathrm{Yb}$, taking the midpoint of the collection period as the time of defaecation. The rest of the faeces were pooled for the analyses of $\mathrm{Cr}$ and nutrients.

To determine the ileal apparent digestibility coefficients, ileal digesta were collected for a total of $12 \mathrm{~h}$ on days 12 and 14 as follows: 0600 to $0800 \mathrm{~h}, 1000$ to $1200 \mathrm{~h}$, and 1400 to $1600 \mathrm{~h}$ (on day 12) and 0800 to 1000,1200 to 1400 , and 1600 to $1800 \mathrm{~h}$ (on day 14). Digesta samples were collected directly into a plastic bag attached to the cannula. The plastic bags were removed every $15 \mathrm{~min}$, weighed, and frozen instantly at $-20^{\circ} \mathrm{C}$. The collected digesta were pooled for analyses of $\mathrm{Cr}$ and nutrients.

\section{Separation of bacterial fraction}

The bacterial fraction of the ileal digesta was isolated from digesta collected after the fifth experimental period. The pigs received the same experimental diets as during the fifth period for an extra 4 days before digesta were collected. To obtain a sufficient amount of bacteria for the analyses, the collected digesta were pooled across fibre levels to two $1000-\mathrm{ml}$ samples, one for diets without and one for diets with the organic acid mixture. Bacteria were isolated from the digesta by a differential centrifugation procedure adapted from Ahvenjärvi et al. (2000). The collected digesta, which were stored at $39^{\circ} \mathrm{C}$ during the collection, were first divided into liquid and solid phases by straining through two layers of cheesecloth. The solid phase remaining on the cheesecloth was washed twice with $250 \mathrm{ml}$ of $0.9 \% \mathrm{NaCl}$ solution $\left(39^{\circ} \mathrm{C}\right)$ and strained through two layers of cheesecloth. The liquid phases were pooled and centrifuged first at $1000 \mathrm{~g}$ for $10 \mathrm{~min}$ to remove feed particles. The collected supernatant was then centrifuged at $10000 \mathrm{~g}$ for $30 \mathrm{~min}$ to sediment bacteria. To remove bacteria from the feed particles, the solid phase that had remained on the cheesecloth was mixed with $800 \mathrm{ml}$ of a solution containing $0.9 \%$ of $\mathrm{NaCl}$ and $0.1 \%$ of carboxymethyl cellulose. The mixture was first kept for $15 \mathrm{~min}$ at $39^{\circ} \mathrm{C}$ and then overnight at $4{ }^{\circ} \mathrm{C}$. The following day, it was strained through two layers of cheesecloth, and the bacteria were isolated from the liquid phase by differential centrifugation as described above. The bacterial pellets were pooled to obtain one sample for diets without and one for diets with the organic acid mixture. They were diluted with distilled water, freeze-dried and analysed for 
dry matter (DM), N, amino acids, total purines, and diaminopimelic acid (DAPA).

\section{Chemical analyses}

The experimental feeds were sampled in each period, analysed for $\mathrm{DM}$ and $\mathrm{pH}$, and the samples were pooled across periods for further analyses. The spot samples of ileal digesta and faeces collected for the determination of passage rate were dried at $60^{\circ} \mathrm{C}$ for $24 \mathrm{~h}$, whereas the ileal digesta and faeces collected for the determination of digestibility coefficients were freeze-dried. The samples were ground to pass through a $1-\mathrm{mm}$ sieve before the analyses.

DM content was determined by drying at $103^{\circ} \mathrm{C}$ for $16 \mathrm{~h}$. The ash, ether extract (after acid hydrolysis), and crude fibre contents were determined using standard methods (Association of Official Analytical Chemists (1990), methods 942.05, 962.09, and 920.39). NDF and ADF were determined according to Van Soest et al. (1991) and Robertson and Van Soest (1981), respectively. N content was determined by the Dumas method with a Leco FP $428 \mathrm{~N}$ analyser (Leco Corp., St Joseph, USA). The dietary $\mathrm{pH}$ of the pelleted feed was measured after this was mixed with water (1:5) and stirred with a magnetic stirrer for 2 min. The contents of DAPA and other amino acids were analysed according to the official method of the European Commission (1998) using a Biochrom 20 amino acid analyser (Biochrom Ltd, Cambridge, UK). The concentrations of purines were determined according to Zinn and Owens (1986), and those of $\mathrm{Cr}, \mathrm{Co}$, and $\mathrm{Yb}$ by atomic absorption spectrophotometry according to Williams et al. (1962). Formic acid was analysed with the UV method using a commercial kit (cat. no. 0979 732, Boehringer Mannheim, R-Biopharm GmbH, Darmstadt, Germany) and the selective clinical chemistry analyser Pro 981489 (KONE Instruments, Espoo, Finland). To obtain supernatant for the formic acid analysis, $10 \mathrm{~g}$ of pelleted feed were mixed with $290 \mathrm{~g}$ of $\mathrm{H}_{2} \mathrm{O}$, stirred twice for $5 \mathrm{~min}$ with $30 \mathrm{~min}$ of cooling (at $-18^{\circ} \mathrm{C}$ ) in between, and then centrifuged at $2000 \mathrm{~g}$ for 10 min. Lactic acid was analysed according to Haacker et al. (1983), short chain fatty acids according to Huhtanen et al. (1998), ammonia according to McCullough (1967), and ATP according to Jensen and Jørgensen (1994).

\section{Calculations and statistical methods}

The apparent digestibility coefficients were calculated by using $\mathrm{Cr}$ as an indigestible marker as follows:

ileal or faecal apparent digestibility coefficient

$$
=1-\left(\mathrm{Cr}_{\mathrm{F}} / \mathrm{Cr}_{\mathrm{D}}\right) \times\left(\mathrm{N}_{\mathrm{D}} / \mathrm{N}_{\mathrm{F}}\right),
$$

where $\mathrm{Cr}_{\mathrm{F}}=$ the content of $\mathrm{Cr}$ in feed, $\mathrm{mg} / \mathrm{kg} \mathrm{DM}, \mathrm{Cr}_{\mathrm{D}}=$ the content of $\mathrm{Cr}$ in digesta or faeces, $\mathrm{mg} / \mathrm{kg} \mathrm{DM}$, $N_{D}=$ the content of nutrient in digesta or faeces, $g / k g$ $\mathrm{DM}$, and $\mathrm{N}_{\mathrm{F}}=$ the content of nutrient in feed, $\mathrm{g} / \mathrm{kg} \mathrm{DM}$.
The flow of bacterial markers (BM), i.e. purines and DAPA, in the ileum was calculated as follows:

$$
\mathrm{BM} \text { flow }(\mathrm{g} / \mathrm{kg} \text { DM intake })=\left(\mathrm{Cr}_{\mathrm{F}} / \mathrm{Cr}_{\mathrm{D}}\right) \times \mathrm{BM}_{\mathrm{D}} \text {, }
$$

where $\mathrm{Cr}_{F}$ and $\mathrm{Cr}_{\mathrm{D}}$ are as mentioned above and $B M_{D}$ is the content of purines or DAPA in digesta, $\mathrm{g} / \mathrm{kg}$ DM. Bacterial $\mathrm{N}$ flow was calculated as follows:

$$
\text { bacterial } \mathrm{N} \text { flow }(\mathrm{g} / \mathrm{kg} \mathrm{DM})=\mathrm{BM} \text { flow } /(\mathrm{BM} / \mathrm{N})_{\mathrm{B}} \text {, }
$$

where $(B M / N)_{B}=$ the ratio of purines of DAPA to $N$ in bacteria isolated from the ileal digesta. Bacterial amino acid flows and contributions were calculated by using the determined amino acids profile of isolated bacteria.

The mean retention time (MRT) of digesta in the terminal ileum and in the whole digestive tract was calculated from the concentration of solute $(\mathrm{Co})$ and particle markers $(\mathrm{Yb})$ in the digesta and faeces according to Faichney (1993) as follows:

$$
t=\Sigma C_{i}^{\prime} t_{i}^{\prime} \Delta t_{i} / \Sigma C_{i}^{\prime} \Delta t_{i},
$$

where $C_{i}$ is the marker concentration at time $t_{i}$ after dosing so that $C_{i}^{\prime}=\left(C_{i}+C_{i-1}\right) / 2, t_{i}^{\prime}=\left(t_{i}+t_{i-1}\right) / 2$, and $\Delta t_{i}=t_{i}-t_{i-1}$. The MRT of digesta in the large intestine was calculated as the difference between the MRT in the whole digestive tract and in the terminal ileum.

The statistical analysis of data was carried out using the GLM procedure of Statistical Analysis Systems Institute (1999) and the following model (Davis and Hall, 1969):

$$
Y_{i j k}=\mu+A_{i}+P_{j}+O_{k}+F_{l}+(O \times F)_{k l}+e_{i j k l},
$$

where $A_{i}$ is the effect of animal $i(i=1-6), P_{j}$ is the effect of experimental period $j(j=1-5), O_{k}$ is the effect of dietary organic acid mixture $k(k=1-2), F_{l}$ is the effect of dietary fibre content $I(I=1-3)$, and $(O \times F)_{k l}$ is the interaction between dietary organic acid mixture and fibre content. It was assumed that no animal $\times$ period interactions existed. Residuals were checked for normality and plotted against fitted values. The effect of dietary fibre level was tested with orthogonal polynomials (linear and quadratic effect). Whenever the probability for an organic acid mixture $\times$ fibre level interaction was $P<0.10$, the differences between the treatments were detected by using the Tukey test (accepted significance level was $<0.05$ ).

\section{Results}

\section{Chemical composition of diets}

The dietary NDF contents averaged 199, 224, and $248 \mathrm{~g} / \mathrm{kg}$ DM for medium-fibre, high-fibre, and very-high-fibre diets, respectively (Table 2 ). The crude protein and amino acid contents were similar in the six experimental diets. The $\mathrm{pH}$ of non-acidified diets decreased from 5.54 to 5.33 with increasing barley fibre inclusions. The dietary organic acid mixture lowered dietary $\mathrm{pH}$ on average to 4.55 irrespective of dietary fibre content, whereas the analysed formic acid contents decreased slightly with increasing fibre content. 
Table 2 Analysed composition of experimental diets with different amounts of fibre content and supplemented with 0 or $8.4 \mathrm{~g} / \mathrm{kg}$ of a mixture of formic acid, sorbate and benzoate

\begin{tabular}{|c|c|c|c|c|c|c|}
\hline \multirow[b]{3}{*}{ Organic acid mixture } & \multicolumn{6}{|c|}{ Fibre content } \\
\hline & \multicolumn{2}{|c|}{ Medium } & \multicolumn{2}{|c|}{ High } & \multicolumn{2}{|c|}{ Very high } \\
\hline & - & + & - & + & - & + \\
\hline Dry matter $(\mathrm{g} / \mathrm{kg})$ & 885 & 885 & 890 & 888 & 890 & 889 \\
\hline \multicolumn{7}{|c|}{ Composition (g/kg dry matter) } \\
\hline Ash & 48 & 48 & 48 & 47 & 50 & 47 \\
\hline Crude protein & 178 & 183 & 179 & 180 & 183 & 170 \\
\hline Ether extract & 30 & 32 & 39 & 40 & 50 & 51 \\
\hline Crude fibre & 48 & 54 & 56 & 58 & 69 & 67 \\
\hline $\begin{array}{l}\text { Neutral-detergent } \\
\text { fibre }\end{array}$ & 198 & 200 & 227 & 220 & 245 & 250 \\
\hline Acid-detergent fibre & 59 & 61 & 68 & 68 & 77 & 80 \\
\hline Alanine & 7.2 & 7.3 & 7.2 & 7.3 & 7.6 & 7.2 \\
\hline Arginine & 9.9 & 10.1 & 10.3 & 10.1 & 10.4 & 10.0 \\
\hline Aspartic acid & 13.4 & 14.0 & 13.6 & 13.7 & 14.2 & 13.6 \\
\hline Cystine & 3.4 & 3.5 & 3.6 & 3.6 & 3.5 & 3.2 \\
\hline Glutamic acid & 31.4 & 31.8 & 31.3 & 31.1 & 33.2 & 31.8 \\
\hline Glycine & 7.2 & 7.1 & 7.2 & 7.2 & 7.4 & 7.1 \\
\hline Histidine & 4.1 & 4.2 & 4.2 & 4.3 & 4.4 & 4.2 \\
\hline Isoleucine & 7.1 & 7.0 & 7.1 & 7.1 & 6.9 & 6.8 \\
\hline Leucine & 12.2 & 12.5 & 12.2 & 12.1 & 12.5 & 11.9 \\
\hline Lysine & 8.7 & 9.0 & 8.9 & 9.0 & 9.1 & 8.6 \\
\hline Methionine & 2.8 & 2.9 & 2.8 & 2.8 & 2.9 & 2.7 \\
\hline Phenylalanine & 8.7 & 8.7 & 8.6 & 8.7 & 8.5 & 8.8 \\
\hline Proline & 14.2 & 13.7 & 13.5 & 12.9 & 13.4 & 12.5 \\
\hline Serine & 8.0 & 8.1 & 7.9 & 8.1 & 8.2 & 8.0 \\
\hline Threonine & 6.4 & 6.5 & 6.3 & 6.4 & 6.5 & 6.3 \\
\hline Tyrosine & 6.0 & 5.9 & 6.0 & 5.9 & 5.9 & 6.0 \\
\hline Valine & 11.6 & 11.4 & 11.5 & 11.5 & 10.6 & 10.8 \\
\hline Formic acid & 0.1 & 7.3 & 0.0 & 6.8 & 0.0 & 5.9 \\
\hline $\mathrm{pH}$ & 5.54 & 4.58 & 5.42 & 4.53 & 5.33 & 4.55 \\
\hline Purines ( $\mathrm{g} / \mathrm{kg}$ dry matter) & 7.6 & 7.2 & 7.6 & 7.5 & 7.6 & 7.7 \\
\hline
\end{tabular}

Health of pigs

The pigs remained healthy and consumed their feed allowances throughout the experiment. They grew at an average rate of $921 \mathrm{~g} /$ day. In the fourth period, the cannula of one pig came off. The pig was tranquillised, and the cannula was reintroduced into the fistula. The pig recovered well, and it was subjected to the experiment procedures as planned, except that ileal digesta samples were not taken for the determination of passage rate. Post-mortem examinations carried out at the conclusion of the experiment revealed no abnormalities or adhesions due to the cannulation, implying that the digestive tract of each pig functioned normally.

\section{Apparent ileal digestibility coefficients}

Table 3 shows that the dietary organic acid mixture improved the ileal apparent digestibility coefficients of crude protein and all amino acids $(P<0.05)$ except for methionine, proline, and valine $(P>0.05)$. The ileal apparent digestibility coefficients of crude protein, cystine, glycine, methionine, proline, threonine, and valine decreased $(P<0.05)$, whereas that of ether extract increased
$(P<0.05)$ in a linear manner with increasing dietary fibre levels. The quadratic effect of fibre level was not significant. A tendency for an organic acid mixture $\times$ fibre level interaction $(P=0.06)$ was found for histidine. The dietary organic acid mixture improved the ileal apparent digestibility of histidine in the high-fibre diet $(P<0.05)$ but not in the medium-fibre or very-high-fibre diets $(P>0.05)$. There was a moderate organic acid mixture $\times$ fibre level interaction $(P=0.07)$ in the ileal digestibility of NDF too. In non-acidified diets, the fibre addition decreased the NDF digestibility in a quadratic manner $(P<0.05)$ but in acidified diets, the effect of fibre level was not significant.

\section{Faecal apparent digestibility coefficients}

A significant $(P<0.05)$ or moderate $(P<0.10)$ organic acid mixture $\times$ fibre level interaction was observed for the faecal digestibility coefficients of all the nutrients except for ADF and hemicellulose (Table 3). The dietary organic acid mixture improved the faecal digestibility of ash and ether extract in medium- and high-fibre diets $(P<0.05)$ but not in the very-high-fibre diet $(P>0.05)$. The faecal digestibility of ether extract increased linearly with increasing dietary fibre levels $(P<0.05)$ in nonacidified diets. The quadratic effect of fibre level was not significant. In diets supplemented with organic acid, the faecal digestibilities of ash, crude protein, NDF, and hemicellulose were lower in the very-high-fibre diet than in the high- and medium-fibre diets $(P<0.05)$, whereas the differences between the latter two were not significant. The faecal apparent digestibility of ether extract was lower in the medium-fibre than in the high-fibre and very-high-fibre diets $(P<0.05)$. The daily excretion of faeces and faecal water content increased linearly with increasing dietary fibre levels $(P<0.05)$ but it was not influenced by the dietary organic acid mixture (results not shown). The recovery of $\mathrm{Cr}$ in faeces averaged $0.99 \pm 0.08$ of intake.

\section{Bacterial nitrogen flow at the ileal and faecal level}

The experimental feeds contained on average $7.5 \pm 0.18 \mathrm{~g}$ purines per $\mathrm{kg}$ of DM (Table 2) but no DAPA was found. The purine/bacterial $\mathrm{N}$ ratio was 1110 and $980 \mathrm{mg} / \mathrm{g}$ and the DAPA/bacterial $\mathrm{N}$ ratio was 34 and $40 \mathrm{mg} / \mathrm{g}$ in bacteria isolated from the ileal digesta of pigs fed diets with 0 or $8.4 \mathrm{~g} / \mathrm{kg}$ of the organic acid mixture, respectively. The amino acid composition of these bacteria averaged as follows: alanine 8.6, arginine 4.4, aspartic acid 9.2, cystine 1.4, glutamic acid 12.4, glycine 4.8, histidine 2.1, isoleucine 4.6, leucine 7.0 , lysine 4.6 , methionine 1.5 , phenylalanine 4.9 , proline 5.0 , serine 4.3 , threonine 4.3 , valine 5.2 , and tyrosine $3.7 \mathrm{~g}$ per $16 \mathrm{~g} \mathrm{~N}$. The differences between the two samples were small, ranging from 0 to $0.3 \mathrm{~g}$ per $16 \mathrm{~g} \mathrm{~N}$, i.e. less than $7 \%$ of the mean.

The concentration of purines in ileal digesta (Table 4) was decreased by the dietary organic acid mixture $(P<0.05)$, whereas the DAPA concentration changed in the opposite direction $(P<0.01)$. Increasing dietary fibre 
Table 3 Apparent ileal and faecal digestibility coefficients of nutrients in experimental diets with different amounts of fibre content and supplemented with 0 or $8.4 \mathrm{~g} / \mathrm{kg}$ of a mixture of formic acid, sorbate and benzoate

\begin{tabular}{|c|c|c|c|c|c|c|c|c|c|c|}
\hline \multirow[b]{3}{*}{ Organic acid mixture } & \multicolumn{6}{|c|}{ Fibre content } & \multirow[b]{3}{*}{ s.e. } & & & \\
\hline & \multicolumn{2}{|c|}{ Medium } & \multicolumn{2}{|c|}{ High } & \multicolumn{2}{|c|}{ Very high } & & \multicolumn{3}{|c|}{ Significance } \\
\hline & - & + & - & + & - & + & & Acid & Fibre & Acid $\times$ fibre \\
\hline \multicolumn{11}{|l|}{ Ileal apparent digestibility } \\
\hline Dry matter ${ }^{\dagger}$ & 0.724 & 0.722 & 0.679 & 0.700 & 0.667 & 0.676 & 0.0074 & & $* * *$ & \\
\hline Crude protein $^{\ddagger}$ & 0.788 & 0.803 & 0.770 & 0.799 & 0.775 & 0.779 & 0.0060 & ** & * & \\
\hline Ether extract ${ }^{\dagger}$ & 0.680 & 0.686 & 0.707 & 0.736 & 0.760 & 0.765 & 0.0089 & १ & $* * *$ & \\
\hline Neutral-detergent fibre & $0.489^{b}$ & $0.391^{\mathrm{ab}}$ & $0.344^{\mathrm{a}}$ & $0.367^{\mathrm{a}}$ & $0.355^{\mathrm{a}}$ & $0.355^{\mathrm{a}}$ & 0.0250 & & $* *$ & १ \\
\hline \multicolumn{11}{|l|}{ Amino acids } \\
\hline Alanine & 0.736 & 0.754 & 0.718 & 0.759 & 0.724 & 0.745 & 0.0077 & $* * *$ & & \\
\hline Arginine & 0.853 & 0.863 & 0.847 & 0.863 & 0.848 & 0.857 & 0.0044 & $* *$ & & \\
\hline Aspartic acid & 0.786 & 0.808 & 0.777 & 0.807 & 0.780 & 0.801 & 0.0055 & $* * *$ & & \\
\hline Cystine $^{\S}$ & 0.817 & 0.832 & 0.817 & 0.828 & 0.806 & 0.814 & 0.0062 & * & १ & \\
\hline Glutamic acid & 0.839 & 0.855 & 0.832 & 0.845 & 0.842 & 0.849 & 0.0051 & ** & & \\
\hline Glycine $^{\ddagger}$ & 0.734 & 0.749 & 0.711 & 0.742 & 0.714 & 0.728 & 0.0067 & ** & * & \\
\hline Histidine & $0.824^{\mathrm{abc}}$ & $0.834^{\mathrm{bc}}$ & $0.807^{a}$ & $0.839^{c}$ & $0.817^{\mathrm{ab}}$ & $0.828^{\mathrm{abc}}$ & 0.0048 & $* * *$ & & ๆ \\
\hline Isoleucine & 0.837 & 0.834 & 0.820 & 0.843 & 0.817 & 0.833 & 0.0058 & * & & \\
\hline Leucine & 0.826 & 0.836 & 0.815 & 0.833 & 0.815 & 0.829 & 0.0052 & $* *$ & & \\
\hline Lysine & 0.825 & 0.841 & 0.815 & 0.847 & 0.819 & 0.834 & 0.0059 & $* * *$ & & \\
\hline Methionine ${ }^{\S}$ & 0.825 & 0.840 & 0.810 & 0.831 & 0.821 & 0.813 & 0.0074 & & & \\
\hline Phenylalanine & 0.809 & 0.811 & 0.791 & 0.813 & 0.787 & 0.811 & 0.0074 & * & & \\
\hline Proline $^{\dagger}$ & 0.845 & 0.837 & 0.819 & 0.817 & 0.814 & 0.802 & 0.0062 & & $* * *$ & \\
\hline Serine & 0.801 & 0.818 & 0.787 & 0.815 & 0.788 & 0.809 & 0.0058 & $* * *$ & & \\
\hline Threonine $^{\S}$ & 0.768 & 0.786 & 0.751 & 0.782 & 0.748 & 0.775 & 0.0064 & $* * *$ & ๆ & \\
\hline Tyrosine & 0.794 & 0.793 & 0.778 & 0.794 & 0.771 & 0.800 & 0.0071 & * & & \\
\hline Valine $^{\ddagger}$ & 0.844 & 0.846 & 0.826 & 0.842 & 0.817 & 0.827 & 0.0065 & ๆ & ** & \\
\hline \multicolumn{11}{|l|}{ Faecal apparent digestibility } \\
\hline Dry matter & $0.832^{c}$ & $0.839^{c}$ & $0.812^{\mathrm{b}}$ & $0.831^{c}$ & $0.786^{\mathrm{a}}$ & $0.789^{\mathrm{a}}$ & 0.0035 & $* *$ & $* * *$ & ף \\
\hline Ash & $0.510^{\mathrm{a}}$ & $0.556^{\mathrm{b}}$ & $0.505^{\mathrm{a}}$ & $0.560^{\mathrm{b}}$ & $0.490^{\mathrm{a}}$ & $0.493^{\mathrm{a}}$ & 0.0084 & $* * *$ & $* * *$ & * \\
\hline Crude protein & $0.810^{\mathrm{abc}}$ & $0.834^{c}$ & $0.801^{\mathrm{ab}}$ & $0.825^{\mathrm{bc}}$ & $0.796^{\mathrm{ab}}$ & $0.785^{\mathrm{a}}$ & 0.0071 & * & $* *$ & * \\
\hline Ether extract & $0.591^{\mathrm{a}}$ & $0.633^{b}$ & $0.656^{\mathrm{b}}$ & $0.704^{c}$ & $0.709^{c}$ & $0.717^{c}$ & 0.0070 & $* * *$ & $* * *$ & * \\
\hline Neutral-detergent fibre & $0.613^{c}$ & $0.566^{\mathrm{bc}}$ & $0.531^{\mathrm{ab}}$ & $0.560^{\mathrm{bc}}$ & $0.485^{\mathrm{a}}$ & $0.480^{\mathrm{a}}$ & 0.0160 & & $* * *$ & ๆ \\
\hline Acid-detergent fibre ${ }^{\dagger}$ & $0.393^{b}$ & $0.404^{b}$ & $0.306^{\mathrm{ab}}$ & $0.385^{\mathrm{b}}$ & $0.274^{\mathrm{a}}$ & $0.303^{\mathrm{ab}}$ & 0.0239 & ๆ & $* * *$ & \\
\hline Hemicellulose & $0.694^{c}$ & $0.638^{b c}$ & $0.627^{\mathrm{ab}}$ & $0.638^{\mathrm{bc}}$ & $0.581^{\mathrm{ab}}$ & $0.564^{\mathrm{a}}$ & 0.0145 & & $* * *$ & ๆ \\
\hline
\end{tabular}

$\mathrm{a}, \mathrm{b}, \mathrm{c}$ Within a row means that have different superscripts differ significantly $(P<0.05)$.

${ }^{\dagger}$ The effect of fibre level is linear $(P<0.001) ;{ }^{\ddagger}(P<0.01) ;{ }^{\S}(P<0.05)$.

"The effect of fibre level is quadratic in non-acidified diets $(P<0.05)$.

"Approaching significance $(P \leq 0.1)$.

levels linearly decreased purine concentration in the ileal digesta $(P<0.01)$ but did not affect DAPA concentration. The ratios of DAPA / total N, purines / total N and DAPA/ purines were larger in pigs fed the diets supplemented with organic acid than those fed non-acidified diets $(P<0.01)$. The DAPA/purine ratio also increased linearly with increasing levels of dietary fibre $(P<0.05)$ but the quadratic effect of fibre level was not significant.

The flow of $\mathrm{N}$ in the ileum was decreased by the dietary organic acid mixture $(P<0.01)$ and it increased linearly with increasing levels of dietary fibre $(P<0.001)$. The quadratic effect of fibre level was not significant. The ileal purine flow was decreased by the dietary organic acid mixture $(P<0.01)$ but it was not influenced by dietary fibre levels $(P>0.05)$. The flow of bacterial $\mathrm{N}$ as assessed by purine flow and the proportion of bacterial $\mathrm{N}$ were decreased by the dietary organic acid mixture $(P<0.01)$ but they were not influenced by dietary fibre levels $(P>0.05)$. Contrary to the situation with purines, the flow of DAPA and bacterial $\mathrm{N}$ as assessed by DAPA flow were increased by the dietary organic acid mixture $(P<0.05)$ and in a linear manner with increasing levels of dietary fibre $(P<0.01)$. The quadratic effect of fibre level was not significant. Based on DAPA, the proportion of bacterial $\mathrm{N}$ was increased by the dietary organic acid mixture $(P<0.01)$ but was not affected by dietary fibre levels $(P>0.05)$.

The dietary organic acid mixture did not affect the faecal purine concentration $(P>0.05)$, which decreased linearly with increasing levels of dietary fibre $(P<0.05)$. The quadratic effect of fibre level was not significant. The faecal flow of total $\mathrm{N}$ and purines was decreased by the dietary organic acid mixture $(P<0.05)$ but the organic 
Organic acid mixtures and dietary fibre effects on digestion in pigs

Table 4 Mean amounts of nitrogen $(N)$, diaminopimelic acid (DAPA), total purines, and bacterial $N$ flow in the ileum and faeces of pigs fed diets with different amounts of fibre content and supplemented with 0 or $8.4 \mathrm{~g} / \mathrm{kg}$ of a mixture of formic acid, sorbate and benzoate

\begin{tabular}{|c|c|c|c|c|c|c|c|c|c|c|}
\hline \multirow[b]{3}{*}{ Organic acid mixture } & \multicolumn{6}{|c|}{ Fibre content } & \multirow[b]{3}{*}{ s.e. } & & & \\
\hline & \multicolumn{2}{|c|}{ Medium } & \multicolumn{2}{|c|}{ High } & \multicolumn{2}{|c|}{ Very high } & & \multicolumn{3}{|c|}{ Significance } \\
\hline & - & + & - & + & - & + & & Acid & Fibre & Acid $\times$ fibre \\
\hline Dry matter (DM) intake (kg/day) & 1.93 & 1.93 & 1.94 & 1.94 & 1.94 & 1.94 & 0.002 & & & \\
\hline \multicolumn{11}{|c|}{ Bacterial markers in ileal digesta (g/kg DM) } \\
\hline Purines $^{\ddagger}$ & 10.6 & 9.7 & 9.9 & 8.7 & 9.2 & 8.0 & 0.42 & ** & ** & \\
\hline Purines to total $\mathrm{N}(\mathrm{g} / \mathrm{g})$ & 0.483 & 0.465 & 0.482 & 0.447 & 0.466 & 0.435 & 0.0138 & * & & \\
\hline DAPA & 0.34 & 0.40 & 0.33 & 0.38 & 0.34 & 0.38 & 0.024 & * & & \\
\hline DAPA to total $N(\mathrm{~g} / \mathrm{g})$ & 0.016 & 0.019 & 0.016 & 0.020 & 0.017 & 0.020 & 0.0011 & $* *$ & & \\
\hline DAPA to purines $(g / g)^{\S}$ & 0.032 & 0.042 & 0.034 & 0.044 & 0.038 & 0.047 & 0.0023 & $* * *$ & $\|$ & \\
\hline \multicolumn{11}{|l|}{ Ileal flow (g/kg DM intake) } \\
\hline Total $\mathrm{N}^{\dagger}$ & 6.27 & 5.88 & 6.43 & 6.07 & 7.07 & 6.51 & 0.176 & ** & $* *$ & \\
\hline Purines & 3.02 & 2.75 & 3.10 & 2.71 & 3.28 & 2.83 & 0.147 & ** & & \\
\hline DAPA $^{\ddagger}$ & 0.096 & 0.113 & 0.103 & 0.118 & 0.123 & 0.132 & 0.0067 & * & ** & \\
\hline \multicolumn{11}{|l|}{ Bacterial $\mathrm{N}$} \\
\hline Purines as bacterial marker & 2.90 & 2.63 & 2.97 & 2.60 & 3.14 & 2.72 & 0.140 & ** & & \\
\hline DAPA as bacterial marker ${ }^{\ddagger}$ & 2.60 & 3.06 & 2.79 & 3.19 & 3.32 & 3.58 & 0.182 & * & ** & \\
\hline \multicolumn{11}{|l|}{ Proportion of bacterial $\mathrm{N}$ (g/total $\mathrm{N}$ ) } \\
\hline Purines as bacterial marker & 0.46 & 0.45 & 0.46 & 0.43 & 0.45 & 0.42 & 0.013 & * & & \\
\hline DAPA as bacterial marker & 0.42 & 0.51 & 0.43 & 0.53 & 0.47 & 0.55 & 0.030 & ** & & \\
\hline Purines in faeces $(\mathrm{g} / \mathrm{kg} \mathrm{DM})^{\S}$ & 14.4 & 12.8 & 13.9 & 12.8 & 12.0 & 12.2 & 0.67 & & $\|$ & \\
\hline \multicolumn{11}{|l|}{ Faecal flow (g/kg DM intake) } \\
\hline Total $\mathrm{N}^{\ddagger}$ & 5.44 & 4.85 & 5.70 & 5.02 & 5.97 & 5.84 & 0.204 & ** & ** & \\
\hline Purines & 2.44 & 2.07 & 2.62 & 2.16 & 2.55 & 2.58 & 0.148 & * & & \\
\hline Bacterial $\mathrm{N}^{\S}$ & 2.20 & 2.13 & 2.37 & 2.21 & 2.31 & 2.62 & 0.139 & & & \\
\hline Proportion of bacterial N (g/total N) & 0.40 & 0.44 & 0.41 & 0.44 & 0.38 & 0.45 & 0.013 & $* * *$ & & \\
\hline
\end{tabular}

${ }^{\dagger}$ The effect of fibre level is linear $(P<0.001) ;{ }^{\ddagger}(P<0.01) ;{ }^{\S}(P<0.05)$.

"Approaching significance $(P<0.1)$.

acid mixture did not affect bacterial $\mathrm{N}$ flow $(P>0.05)$. Faecal total $\mathrm{N}$ flow increased linearly with increasing dietary fibre levels, whereas purine and bacterial $\mathrm{N}$ flows did not change $(P>0.05)$. Because no bacteria were isolated from the faeces, the determined ileal purine / bacterial $\mathrm{N}$ ratios were used in calculations. The proportion of bacterial $\mathrm{N}$ in the faeces was higher in diets with than without the organic acid mixture $(P<0.001)$ but it was not influenced by dietary fibre levels $(P>0.05)$.

When using purines as the bacterial marker, the dietary organic acid mixture decreased the proportion of bacterial amino acids in ileal digesta $(P<0.05)$ but this proportion was not influenced by dietary fibre levels $(P>0.05)$ (results not shown). The decreasing effect of dietary organic acid mixture $(P<0.05)$ on the total and bacterial flow of alanine, isoleucine, leucine, and lysine in the ileum as assessed by purine flow is presented in Figure 1. The share of these amino acids produced by bacteria represented over 0.60 of the total amount of amino acids flowing in the ileum. The opposite observation was made with DAPA as the bacterial marker, for the dietary organic acid mixture increased the proportion of bacterial amino acids in the ileal digesta $(P<0.05)$, except in the case of cysteine and proline (results not shown). In addition, increasing levels of dietary fibre increased the proportions of bacterial arginine, histidine, isoleucine, leucine, lysine, and tyrosine in a linear manner $(P<0.05)$.

\section{Microbial metabolites and activity}

The $\mathrm{pH}$ of ileal digesta was not influenced by the dietary treatments $(P>0.05$; Table 5$)$. The dietary organic acid mixture lowered ileal concentration of lactic acid $(P<0.05)$ and increased that of acetic acid $(P<0.001)$. Concentrations of other microbial metabolites were not influenced by the dietary organic acid mixture $(P>0.05)$. Dietary fibre levels had a quadratic effect on ileal concentrations of acetic, propionic, butyric, and isovaleric acid $(P<0.01)$, the concentrations being lowest in the highfibre diet. The molar proportions of volatile fatty acids did not differ between the dietary treatments $(P>0.05)$. The ATP content of the ileal digesta was not influenced by the dietary organic acid mixture $(P>0.05)$ but it decreased linearly with increased dietary fibre level $(P<0.05)$. The quadratic effect of fibre level was not significant.

The rate of passage

The MRT values of $\mathrm{Co}$ and $\mathrm{Yb}$ in the terminal ileum, in the large intestine, and in the whole digestive tract are presented in Table 6 . Neither the dietary organic acid 
Partanen, Jalava and Valaja

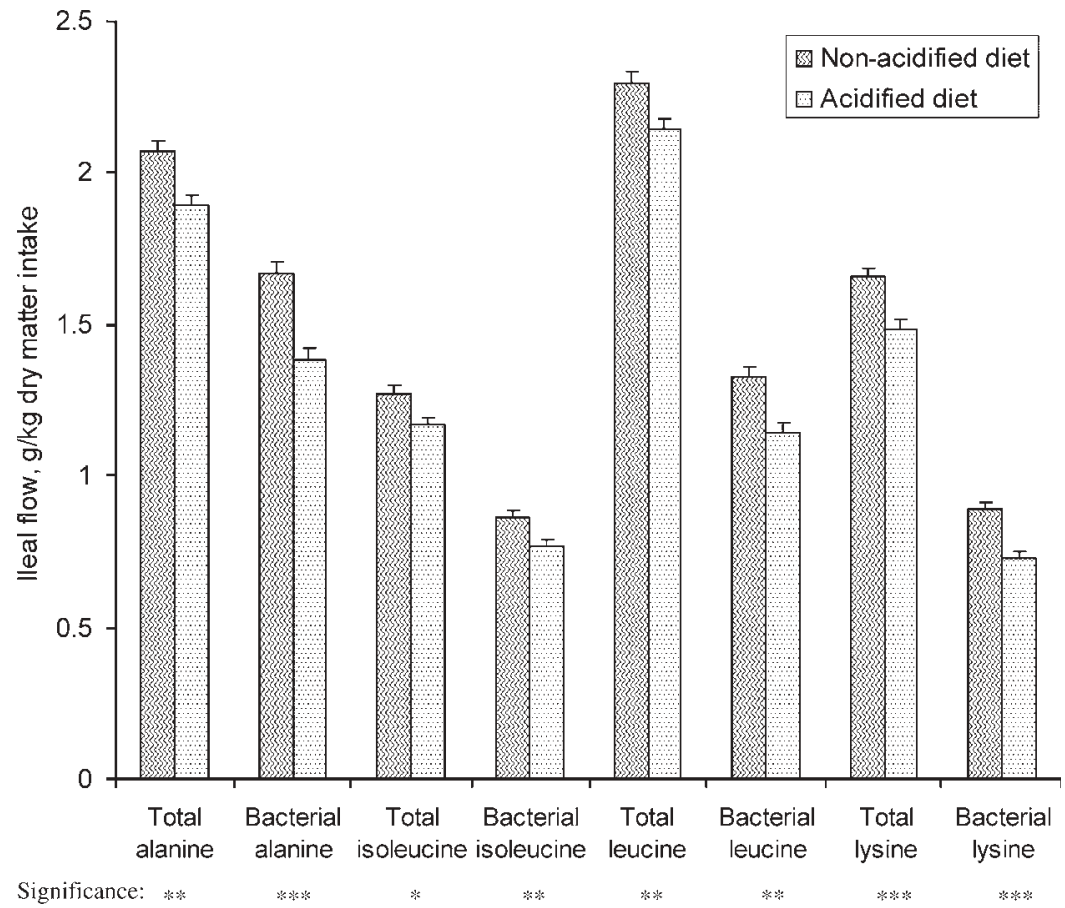

Figure 1 Flows of total and bacterial alanine, isoleucine, leucine, and lysine ( $\mathrm{g} / \mathrm{kg}$ dry matter intake) in the ileum of pigs fed diets with 0 or $8.4 \mathrm{~g} / \mathrm{kg}$ of a mixture of formic acid, sorbate and benzoate. The bacterial amino acid flows were calculated using total purines as the bacterial marker.

mixture nor fibre levels influenced the MRT of $\mathrm{Co}$ and $\mathrm{Yb}$ in the terminal ileum $(P>0.05)$. The MRT of $\mathrm{Co}$ and $\mathrm{Yb}$ in the large intestine and in the whole digestive tract decreased linearly with increasing fibre levels $(P<0.01)$ but the quadratic effect of fibre level was not significant. The MRT of $\mathrm{Co}$ and $\mathrm{Yb}$ was not affected by the dietary organic acid mixture $(P>0.05)$. The faecal recovery of
Co and $\mathrm{Yb}$ averaged $0.89 \pm 1.13$ and $0.78 \pm 0.11$ of intake, respectively.

\section{Discussion}

The diets based on barley and soya-bean meal and with medium, high, or very high fibre levels contained 0,75 , or

Table 5 Mean values of $\mathrm{pH}$, ammonia, formic acid, lactic acid, volatile fatty acids (VFA), and ATP in the ileal digesta of pigs fed diets with different amounts of fibre content and supplemented with 0 or $8.4 \mathrm{~g} / \mathrm{kg}$ of a mixture of formic acid, sorbate and benzoate

\begin{tabular}{|c|c|c|c|c|c|c|c|c|c|c|}
\hline \multirow[b]{3}{*}{ Organic acid mixture } & \multicolumn{6}{|c|}{ Fibre content } & \multirow[b]{3}{*}{ s.e. } & \multirow{2}{*}{\multicolumn{3}{|c|}{ Significance }} \\
\hline & \multicolumn{2}{|c|}{ Medium } & \multicolumn{2}{|c|}{ High } & \multicolumn{2}{|c|}{ Very high } & & & & \\
\hline & - & + & - & + & - & + & & Acid & Fibre & Acid $\times$ fibre \\
\hline $\mathrm{pH}$ & 5.7 & 5.8 & 5.9 & 6.0 & 6.0 & 6.0 & 0.16 & & & \\
\hline Ammonia (mmol/l) & 1.94 & 2.18 & 2.10 & 1.98 & 2.05 & 1.71 & 0.168 & & & \\
\hline Formic acid (mmol/l) & 1.14 & 1.99 & 5.25 & 6.61 & 3.07 & 3.62 & 1.901 & & & \\
\hline Lactic acid $(\mathrm{mmol} / \mathrm{l})$ & 43.6 & 26.3 & 48.0 & 31.9 & 35.6 & 28.0 & 5.92 & * & & \\
\hline \multicolumn{11}{|l|}{ VFA (mmol/l) } \\
\hline Acetic acid ${ }^{\dagger}$ & 46.3 & 55.7 & 30.5 & 43.3 & 39.6 & 52.6 & 2.98 & $* * *$ & ** & \\
\hline Propionic acid ${ }^{\dagger}$ & 27.3 & 26.9 & 14.7 & 18.6 & 23.8 & 26.0 & 2.44 & & ** & \\
\hline Butyric acid $^{\ddagger}$ & 7.13 & 10.60 & 4.68 & 5.89 & 8.41 & 7.86 & 1.225 & & * & \\
\hline Isovaleric acid & 2.02 & 2.55 & 1.19 & 1.43 & 2.89 & 2.01 & 0.558 & & & \\
\hline \multicolumn{11}{|l|}{ VFA molar proportions } \\
\hline Acetic acid & 0.58 & 0.60 & 0.61 & 0.61 & 0.55 & 0.60 & 0.025 & & & \\
\hline Propionic acid & 0.32 & 0.27 & 0.28 & 0.28 & 0.31 & 0.29 & 0.015 & $\|$ & & \\
\hline Butyric acid & 0.08 & 0.11 & 0.09 & 0.09 & 0.10 & 0.09 & 0.011 & & & \\
\hline Isovaleric acid & 0.02 & 0.02 & 0.02 & 0.02 & 0.04 & 0.02 & 0.006 & & & \\
\hline ATP $(\mathrm{mmol} / /)^{\S}$ & 65.1 & 62.3 & 60.1 & 57.2 & 51.0 & 50.7 & 4.52 & & * & \\
\hline
\end{tabular}

${ }^{\dagger}$ The effect of fibre level is quadratic $(P<0.001) ;{ }^{\ddagger}(P<0.01)$.

${ }^{\S}$ The effect of fibre level is linear $(P<0.05)$.

"Approaching significance $(P \leq 0.1)$. 
Table 6 Mean retention time of solute $(\mathrm{CO})$ and particle $(\mathrm{Yb})$ markers in the upper and lower gut and the whole digestive tract of pigs fed diets with different amounts of fibre content and supplemented with 0 or $8.4 \mathrm{~g} / \mathrm{kg}$ of a mixture of formic acid, sorbate and benzoate

\begin{tabular}{|c|c|c|c|c|c|c|c|c|c|c|}
\hline \multirow[b]{3}{*}{ Organic acid mixture } & \multicolumn{6}{|c|}{ Fibre content } & \multirow[b]{3}{*}{ s.e. } & \multirow{2}{*}{\multicolumn{3}{|c|}{ Significance }} \\
\hline & \multicolumn{2}{|c|}{ Medium } & \multicolumn{2}{|c|}{ High } & \multicolumn{2}{|c|}{ Very high } & & & & \\
\hline & - & + & - & + & - & + & & Acid & Fibre & Acid $\times$ fibre \\
\hline \multicolumn{11}{|c|}{ Stomach and small intestine } \\
\hline Co (h) & 7.2 & 7.7 & 7.8 & 7.6 & 7.7 & 7.9 & 0.21 & & & \\
\hline $\mathrm{Yb}(\mathrm{h})$ & 10.4 & 11.2 & 11.0 & 10.7 & 10.8 & 11.2 & 0.23 & & & $\neq$ \\
\hline \multicolumn{11}{|l|}{ Large intestine } \\
\hline $\mathrm{Co}(\mathrm{h})^{\dagger}$ & 34.1 & 33.9 & 32.7 & 34.1 & 27.6 & 30.3 & 1.32 & & ** & \\
\hline $\mathrm{Yb}(\mathrm{h})^{\dagger}$ & 33.6 & 32.9 & 31.8 & 32.9 & 26.9 & 29.8 & 1.39 & & ** & \\
\hline \multicolumn{11}{|l|}{ Entire digestive tract } \\
\hline Co $(h)^{\dagger}$ & 41.3 & 41.7 & 40.5 & 41.6 & 35.3 & 38.2 & 1.33 & & ** & \\
\hline $\mathrm{Yb}(\mathrm{h})^{\dagger}$ & 44.0 & 44.1 & 42.8 & 43.6 & 37.7 & 41.1 & 1.38 & & ** & \\
\hline
\end{tabular}

${ }^{\dagger}$ The effect of fibre level is linear $(P<0.01)$.

${ }^{\ddagger}$ Approaching significance $(P \leq 0.1)$.

$150 \mathrm{~g} / \mathrm{kg}$ of barley fibre that was a by-product of integrated starch-ethanol production. Barley fibre consists mainly of endosperm cell-wall material and is rich in both NDF and $A D F$, whereas the starch content is low. Its crude protein content and the protein's amino acid profile are similar to that of barley (Partanen et al., 1998). Although dietary soya-bean meal levels were increased slightly with increasing barley fibre inclusion levels, the dietary amino acid composition hardly changed. The dietary $\mathrm{pH}$ decreased with increasing barley fibre inclusions, which is explained by the lower $\mathrm{pH}$ of barley fibre (below 3.5) compared with that of barley (5.8) and soya-bean meal (6.8). The dietary organic acid mixture consisted primarily of formic acid, and it lowered the dietary pH by 0.78 to $0.96 \mathrm{pH}$ units, which is in agreement with previous studies (Partanen et al., 2001; Mroz et al., 2000). The pH-lowering effect of the organic acid mixture was greatest in the medium-fibre diet, and $100 \%$ of the added formic acid was recovered in the analyses of this diet. The $\mathrm{pH}$ change became smaller with increasing dietary barley fibre content, and 93 and $81 \%$ of the added formic acid was recovered from the high-fibre and very-high-fibre diets, respectively. Because no mistakes were noticed in feed mixing, it seems that the barley fibre, which has a good water-holding capacity, may have absorbed and retained formic acid so that it was not released completely when the pelleted feed was mixed with water to measure $\mathrm{pH}$ and to extract formic acid for the analyses.

The dietary organic acid mixture improved the ileal apparent digestibility of protein and of 14 of the 17 amino acids analysed. Improved ileal amino acid apparent digestibilities have been reported when diets for growing-finishing pigs have been supplemented with propionic (Mosenthin et al., 1992), lactic (Kemme et al., 1999), formic (Mroz et al., 2000; Partanen et al., 2001), butyric, or fumaric acid (Mroz et al., 2000). In the present experiment, the ileal amino acid apparent digestibilities were improved by 0.015 to 0.027 . Somewhat larger improvements were reported in the aforementioned studies, which could have been a result of differences in the acid added and the inclusion levels used and diet composition. In this study, the greatest improvements were seen in the ileal apparent digestibility of alanine, threonine, aspartic acid, serine, lysine, and glycine. A tendency for an interaction was found for the apparent ileal digestibility of histidine $(P=0.06)$, which was improved in the medium- and highfibre diets $(P<0.05)$ but not in the very-high-fibre diet. In the study of Partanen et al. (2001), dietary NDF levels of 189 and $219 \mathrm{~g} / \mathrm{kg} \mathrm{DM}$ were obtained by adding 0 or $180 \mathrm{~g} / \mathrm{kg}$ of wheat bran/middlings to a diet based on barley and soya-bean meal. That fibre addition reduced the ileal amino acid apparent digestibilities more than the barley fibre additions in this study, and the dietary formic acid in that study improved the ileal amino acid apparent digestibilities only in the high-fibre diet.

Increasing dietary fibre levels resulted in a linear decrease in the ileal apparent digestibility of crude protein and of six of the 17 amino acids analysed. Similarly, increasing inclusions (0 to $167.5 \mathrm{~g} / \mathrm{kg} \mathrm{DM}$ ) of barley fibre in semipurified barley-distiller's feed diets have decreased the ileal apparent digestibility coefficients of amino acids by 0.005 to 0.008 per each $10-\mathrm{g}$ increase in dietary NDF content (Partanen et al., 1998). In this study, the ileal amino acid apparent digestibilities decreased slightly less. The high-fibre and very-high-fibre diets contained rapeseed oil, which has been shown to improve the ileal apparent digestibility of amino acids (Li and Sauer, 1994). Thus, rapeseed oil additions may have partly diminished the negative effect of barley fibre on ileal amino acid apparent digestibility. In addition to the quantity of dietary fibre, its quality may determine how large an effect fibre has on ileal amino acid apparent digestibilities (Sauer et al., 1991; Mosenthin et al., 1994). Huang et al. (2001) found that the ileal apparent digestibilities of several amino acids negatively correlated with the crude protein content associated with NDF in wheat fractions. Poorly digestible cell 
walls can protect protein from proteolytic enzymes, resulting in poorer amino acid digestibilities.

Amino acids in ileal digesta can originate from undigested feed proteins, various endogenous secretions, sloughed epithelial cells, and microbes. Dietary formic acid has been shown not to influence the secretion of pancreatic juice (Lesniewska et al., 2001), whereas dietary soluble fibres have been shown to increase the secretion of saliva, gastric and pancreatic juices, and bile considerably (Mosenthin et al., 1994). Endogenous secretions provide an easily available $\mathrm{N}$ source for bacteria (Bartelt et al., 1999). In addition, the carbohydrate composition of a diet has a distinct influence on the microbial fermentation and the de novo synthesis of bacterial amino acids in the small intestine (Wenk, 2001). In this study, bacterial N contributed 0.42 to 0.46 and 0.42 to 0.55 of $\mathrm{N}$ in the ileum, as assessed by purine and DAPA flows, respectively. These proportions are within the wide range of values reported in the literature using both bacterial markers (Wünsche et al., 1991; Schulze et al., 1994; Bartelt et al., 1999; Huang et al., 2001; Partanen et al., 2001).

The bacterial marker DAPA is a component of the peptidoglycan layer of the bacterial cell wall; it is not found in animal or plant cells (Czerkawski and Faulds, 1974). Purines from hydrolysed nucleic acids are not as specific to bacteria as DAPA, and those purines found in digesta can originate from microbes, undigested diet, mucosal secretions, and sloughed off cells (Zinn and Owens, 1986). The purine / bacterial $\mathrm{N}$ ratio was 1110 and $980 \mathrm{mg} / \mathrm{g}$ in the two bacterial isolates. References for purine / bacterial $\mathrm{N}$ ratios in ileal and faecal bacteria of pigs were not found in the literature, but the determined ratios are in agreement with values reported for ruminal microbes (IIlg and Stern, 1994). The DAPA / bacterial N ratios of 34 and $40 \mathrm{mg} / \mathrm{g}$ are among the highest reported in the literature. Bartelt et al. (1999) obtained DAPA / bacterial $\mathrm{N}$ ratios of 34.4 and $22.3 \mathrm{mg} / \mathrm{g}$ for miniature and domestic pigs with re-entrant ileo-caecal cannulae. Köhler et al. (1992) reported somewhat lower values for pigs with PVTC cannulae $(13.9$ to $16.7 \mathrm{mg} / \mathrm{g})$ and ileo-rectal anastomosis $(14.3$ to $27.5 \mathrm{mg} / \mathrm{g}$ ). In the study of Wünsche et al. (1991), the DAPA / bacterial $\mathrm{N}$ ratios were 7.5 to $18.8 \mathrm{mg} / \mathrm{g}$ for pigs with re-entrant ileo-caecal cannulae and 10 to $39.6 \mathrm{mg} / \mathrm{g}$ for pigs with ileo-rectal anastomoses. In the PVTC cannulation, the caecum is removed, and reflux of digesta from colon to ileum can influence microbial populations in the terminal ileum. According to Wünsche et al. (1991), the variation in DAPA / bacterial $\mathrm{N}$ ratios is high, the coefficient of variation being over $20 \%$. Based on the observed high DAPA to bacterial $\mathrm{N}$ ratio, the contribution of bacterial $\mathrm{N}$ to ileal $\mathrm{N}$ flow may even be underestimated at 0.42 to 0.55 .

The dietary organic acid mixture decreased the ileal flow of purines and bacterial $\mathrm{N}$ as assessed by purine flow. These findings are in close agreement with the results of Partanen et al. (2001). They support the hypothesis that improved apparent ileal amino acid digestibilities seen in diets supplemented with organic acid arise at least partly from decreased bacterial protein synthesis in the ileum. Over 0.60 of alanine, isoleusine, leucine, and lysine found in the ileal digesta was of bacterial origin as assessed by purine flow, and the improvements seen in the apparent ileal digestibility of these amino acids were primarily a result of decreased bacterial amino acid flows in the ileum. The contribution of bacterial amino acids was the lowest for proline, glycine, and glutamic acid. These are the amino acids that are among the most abundant ones in endogenous protein (Stein et al., 1999).

Increased dietary fibre levels did not affect the bacterial $\mathrm{N}$ flow in the ileum as assessed by purine flow, which is in agreement with our previous results (Partanen et al., 2001). In the studies of Schulze et al. (1994) and Bartelt et al. (1999), increasing fibre inclusions did not affect bacterial $\mathrm{N}$ flow as assessed by DAPA flow. In this study, however, increasing levels of dietary fibre increased the flow of DAPA and consequently of bacterial $\mathrm{N}$ flow as assessed by DAPA flow. The dietary organic acid mixture increased DAPA flow too. The contradictory results obtained with purines and DAPA indicate that the common assumption of a constant DAPA / bacterial $\mathrm{N}$ or purine / bacterial $\mathrm{N}$ ratio could be misleading. This is supported by the observation that the DAPA/purine ratio was changed by both the dietary organic acid mixture and increased fibre levels. The DAPA/purine ratio of digesta averaged 0.035 and $0.044 \mathrm{~g} / \mathrm{g}$ in pigs fed diets without and with organic acid supplementation, and a similar difference was seen in the DAPA / purine ratio of bacteria that were isolated from digesta ( 0.031 and $0.041 \mathrm{~g} / \mathrm{g}$, respectively). According to Dufva et al. (1982), the concentration of DAPA can vary greatly among different species of bacteria in the rumen. References for DAPA / bacterial $\mathrm{N}$ ratios of bacteria found from the digestive tract of pigs are scarce. Laplace et al. (1985) reported a DAPA / bacterial $\mathrm{N}$ ratio of 24.8 for a pure $E$. coli culture and values of 29.9 and $19.9 \mathrm{~g} / \mathrm{g}$ in bacteria isolated from the faeces of pigs fed standard and semi-synthetic diets, respectively. The latter figures support the conclusion that the use of a constant DAPA / bacterial $\mathrm{N}$ ratio could be misleading.

Comparisons of DAPA and purines as bacterial markers in pigs are scarce. In dogs, the use of DAPA as a bacterial marker resulted in a smaller standard error for bacterial $\mathrm{N}$ than purines (Karr-Lilienthal et al., 2004). In this study, the standard error of the mean for bacterial $\mathrm{N}$ flow in the ileum was smaller when bacterial $\mathrm{N}$ flow was assessed by means of purines rather than DAPA. This speaks in favour of the use of purines as a bacterial marker to estimate bacterial $\mathrm{N}$ flow in the ileum of pigs. However, dietary purines may not be completely digested, and undigested purines as well as purines from endogenous secretions may confound the measurements of purine concentrations in digesta. It would have been better to isolate bacterial fractions from ileal digesta from each pig during each experimental period instead of obtaining only two pooled samples. However, this would have required the collection 
of considerably larger amounts of digesta because we were able to obtain only about $3.2 \mathrm{~g}$ bacterial DM per $\mathrm{kg}$ fresh ileal digesta. Furthermore, it seems that both the endogenous and bacterial $\mathrm{N}$ flows should have been determined to find out why dietary organic acid mixture improved the ileal apparent digestibility of amino acids.

Estimates of bacterial $\mathrm{N}$ contribution in faeces have ranged greatly depending on diet composition and the method of determination (Dierick et al., 1990: Sauer et al., 1991). Dietary fibre generally stimulates microbial activity and bacterial protein synthesis in the large intestine (Wenk, 2001). In this study too, faecal bacterial $\mathrm{N}$ flow increased linearly with increasing dietary fibre levels. The dietary organic acid mixture did not affect the faecal bacterial $\mathrm{N}$ flow, but it increased the proportion of bacterial $\mathrm{N}$ in faeces. This supports the hypothesis that dietary organic acids restrict microbial fermentation in the small intestine, and this restriction could result in increased amounts of carbohydrates being fermented in the large intestine. Because faecal bacteria were not isolated and analysed for bacterial marker, the obtained faecal bacterial $\mathrm{N}$ flows should be considered as rough estimates.

Both the ileal and faecal apparent digestibility of ether extract improved with higher dietary fibre levels. The diets were formulated to be isoenergetic, and so rapeseed oil was added to medium- and high-fibre diets. The higher the ether extract content, the higher is the ileal and faecal apparent digestibility of ether extract (Jørgensen et al., 1992). The dietary organic acid mixture improved the faecal digestibility of ether extract, whereas it produced only a tendency towards improvement in ileal apparent digestibility. The positive effect of organic acid on ether extract digestibility is in agreement with previous results (Mroz et al., 2000; Partanen et al., 2001) and it may result from changes in microbial activity in the digestive tract. Microbial deconjugation and dehydroxylation of bile impair lipid absorption by the host animal. Lactobacilli inhabiting the small intestine may be largely responsible for bile salt hydrolysis (Anderson et al., 1999). In this study, ileal lactic acid concentrations were reduced by the dietary organic acid mixture, indicating that the growth of lactic acid bacteria was restricted. Faecal ether extract digestibilities were lower than ileal ones, which is in accordance with our previous results (Partanen et al., 2001) and could have been caused by microbial fat synthesis in the large intestine (Dierick et al., 1990).

Both the dietary organic acid mixture and higher fibre levels resulted in changes in microbial metabolite concentrations in the ileal digesta. The dietary organic acid mixture decreased the lactic acid and increased the acetic acid concentration. Reduced lactic acid concentration in the stomach and small intestine of pigs has been reported when diets have been supplemented with formic acid or formates (Roth et al., 1992; Partanen et al., 2001; Canibe et al., 2005). The decrease in lactic acid concentration may result from a reduction in microbial fermentation of glucose from starch hydrolysis. Bacteria compete with the host for nutrients in the stomach and small intestine. The reduced production of lactic acid may enable the increased absorption of glucose in the small intestine. The increased acetic acid concentrations seen in the diets supplemented with formic acid are also in agreement with previous results (Roth et al., 1992; Partanen et al., 2001). The decreased lactic acid and increased acetic acid production observed indicate that a shift may have occurred in the composition of the small intestine's bacterial flora. Dietary carbohydrate composition has a profound effect on microbial fermentation and metabolite concentrations in the ileum (Dierick et al., 1990). In this study, fibre level had a quadratic effect on concentrations of acetic, propionic, and butyric acid, and the lowest concentrations were observed in the medium-fibre diet. The concentration of ATP is used to estimate microbial activity in the gastrointestinal tract of monogastric animals (Jensen and Jørgensen, 1994). In this study, the ileal ATP concentrations decreased with increasing dietary fibre levels, which indicates that the carbohydrates of high-fibre and very-highfibre diets were less fermentable and decreased microbial activity in the small intestine compared with barley-based medium-fibre diet.

The MRT of the solute marker Co was ca $3.2 \mathrm{~h}$ shorter than that of the particle marker $\mathrm{Yb}$ in the terminal ileum, whereas the MRT in the large intestine was fairly similar for both markers. Neither dietary organic acid supplementation nor fibre level influenced the MRT of $\mathrm{Co}$ and $\mathrm{Yb}$ in the terminal ileum, which indicates that improvements seen in the ileal apparent digestibility of amino acids were not caused by changes in digesta passage rate. According to Wenk (2001), soluble fibres can increase the passage rate of digesta in the upper digestive tract, but we did not see such an effect.

Dietary organic acid supplementation did not influence the MRT of $\mathrm{Co}$ and $\mathrm{Yb}$ in the large intestine or the whole digestive tract. Fibre addition resulted in linearly decreasing MRT in the large intestine and the whole digestive tract, which is in agreement with previous findings (Wenk, 2001). The MRT of markers in the whole digestive tract are similar to those reported for diets based on maize and soya-bean meal by Pond et al. (1986). The amount of faeces collected from the pigs during the 4-day period increased linearly from 1.12 to $1.43 \mathrm{~kg} /$ day. This was primarily caused by linearly increased excretion of water (from 0.81 to $1.05 \mathrm{~kg} /$ day) in faeces, which is in agreement with previous reports (Wenk, 2001). DM excretion increased too, but less (from 0.32 to $0.39 \mathrm{~kg} /$ day), which is explained by the poorer digestibility of barley fibre compared with that of barley.

\section{Conclusions}

The results show that a dietary mixture of formic acid, sorbate, and benzoate has a positive effect on the ileal apparent digestibility of protein and all amino acids except for methionine, proline, and valine. The faecal digestibility coefficients of crude protein and ether extract 
improved too, but the effect of the organic acid mixture was dependent on the dietary fibre level. The bacterial markers purines and DAPA showed opposite effects on bacterial $\mathrm{N}$ flow in the ileum, which makes the use of a constant bacterial marker / bacterial $\mathrm{N}$ ratio questionable for the estimation of bacterial $\mathrm{N}$ flow in the ileum. For the same reason, the hypothesis that dietary organic acids decrease the contribution of bacterial protein in the ileal digesta could not be confirmed. The dietary organic acid mixture reduced lactic acid and increased acetic acid concentrations in the ileum, whereas the concentrations of acetic, propionic, and butyric acid were lower in the highfibre diet than in the medium-fibre and very-high fibre diets. The improved ileal and faecal apparent digestibilities seen in the diets supplemented with organic acid were not explained by MRT in the terminal ileum. Dietary fibre addition shortened the MRT of digesta in the large intestine, and it increased both faecal water and DM excretion.

\section{Acknowledgements}

This research was financially supported by Kemira Chemicals, Ltd., Formics, Finland. The authors wish to thank the staff of Animal Production Research at MTT Agrifood Research Finland who cared for the experimental animals and carried out the laboratory analyses.

\section{References}

Ahvenjärvi S, Vanhatalo A, Huhtanen P and Varvikko T 2000. Determination of reticulo-rumen and whole stomach digestion in lactating cows by omasal canal and duodenal sampling. British Journal of Nutrition 83, 67-77.

Anderson DB, McCracken VJ, Aminov RI, Simpson JM, Mackie RI, Verstegen MWA and Gaskins HR 1999. Gut microbiology and growth-promoting antibiotics in swine. Pig News and Information 20,115N-122N.

Association of Official Analytical Chemists 1990. Official methods of analysis. AOAC, Arlington, VA.

Bartelt J, Drochner W, Götz K-P, Sxakacz J, Ceresnáková Z and Sommer A 1999. Determination of endogenous nitrogen associated with bacteria in ileal digesta of pigs receiving cereal-based diets with or without fish meal and various fibre supplements by using a simple ${ }^{15} \mathrm{~N}$-dilution technique. Journal of Animal and Feed Sciences 8, 425-440.

Beauchemin KA and Buchanan-Smith JG 1989. Evaluation of markers, sampling sites and models for estimating rates of passage of silage or hay in dairy cows. Animal Feed Science and Technology 27, 59-75.

Canibe N, Højberg 0, Højsgaard S and Jensen BB 2005. Feed physical form and formic acid addition to the feed affect the gastrointestinal ecology and growth performance of growing pigs. Journal of Animal Science 83, 12871302.

Czerkawski JW and Faulds C 1974. Methods for determining 2-6-diaminopimelic acid and 2-aminoethylphosphonic acid in gut contents. Journal of the Science of Food and Agriculture 25, 45-55.

Davis A and Hall WB 1969. Cyclic change-over designs. Biometrika 56, 283293.

Dierick NA, Vervaeke IJ, Decuypere JA and Henderickx HK 1990. Bacterial protein synthesis in relation to organic matter digestion in the hind gut of growing pigs; contribution of hindgut fermentation to total energy supply and growth performance. Journal of Animal Physiology and Animal Nutrition 63, 220-235.

Dufva GS, Bartley EE, Arambel MJ, Nagaraja TG, Dennis SM, Galitzer SJ and Dayton AD 1982. Diaminopimelic acid content of feeds and rumen bacteria and its usefulness as a rumen bacterial marker. Journal of Dairy Science 65, 1754-1759.
European Commission 1998. Commission Directive 98/64/EC. Community methods of analysis for the determination of amino acids, crude oils and fats, and olaquindox in feeding stuffs and amending Directive 71/393/EEC. Official Journal of European Commission L257, 14-28.

Faichney GJ 1993. Digesta flow. In Quantitative aspects of ruminantdigestion and metabolism (ed. JM Forbes and J France), pp. 6-214. CAB International, Wallingford.

Haacker K, Block HJ and Weissbach F 1983. Zur kolorimetrischen Milchsäurebestimmung in Silagen mit p-Hydroxydiphenyl. Archiv Für Tierernährung 33, 505-512.

Huang SX, Sauer WC and Marty B 2001. Ileal digestibilities of neutral detergent fiber, crude protein, and amino acids associated with neutral detergent fiber in wheat shorts for growing pigs. Journal of Animal Science 79, 23882396

Huhtanen P, Blauwiekel R and Saastamoinen I 1998. Effects of intraruminal infusion of propionate and butyrate with two different protein supplements on milk production and blood metabolites in dairy cows receiving grass silage-based diet. Journal of the Science of Food and Agriculture 77, 213-222.

Illg DJ and Stern MD 1994. In vitro and in vitro comparisons of diaminopimelic acid and purines for estimating protein synthesis in the rumen. Animal Feed Science and Technology 48, 49-55.

Jørgensen $\mathrm{H}$, Jakobsen $\mathrm{K}$ and Eggum BO 1992. Excretion of biliary fat and fatty acids in growing pigs. Journal of Animal and Feed Sciences 1, 139-149.

Jensen BB and Jørgensen H 1994. Effect of dietary fiber on microbial activity and microbial gas production in various regions of the gastrointestinal tract of pigs. Applied and Environmental Microbiology 60, 1897-1904.

Kemme PA, Jongbloed AW, Mroz Z, Kogut J and Beynen AC 1999. Digestibility of nutrients in growing-finishing pigs is affected by Aspergillus niger phytase, phytate and lactic acid levels. 1. Apparent ileal digestibility of amino acids. Livestock Production Science 58, 107-117.

Karr-Lilienthal LK, Grieshop CM, Spears JK, Patil AR, Czarnecki-Maulden GL, Merchen NR and Fahey GC Jr 2004. Estimation of the proportion of bacterial nitrogen in canine feces using diaminopimelic acid as an internal bacterial marker. Journal of Animal Science 82, 1707-1712.

Köhler T, Mosenthin R, Verstegen MWA, Huisman J, Den Hartog LA and Ahrens $F$ 1992. Effect of ileo-rectal anastomosis and post-valve T-caecaum cannulation on growing pigs. 1. Growth performance, N-balance and intestinal adaptation. British Journal of Nutrition 68, 293-303.

Laplace J-P, Darcy-Vrillon B, Duval-Iflah Y and Raibaud P 1985. Proteins of the digesta of the pig: amino acid composition of endogenous, bacterial and faecal fractions. Reproduction, Nutrition, Development 25, 1083-1099.

Lesniewska V, Lærke HN, Hedemann MS and Jensen BB 2001. Effect of intraduodenal infusion of lactic acid and formic acid on pancreatic juice secretion and antroduodenal myoelectrical acticity in piglets after weaning. In Digestive physiology of pigs (ed. JE Lindberg and B Ogle), pp. 215-217. CABI Publishing, Wallingford.

Li S and Sauer WC 1994. The effect of dietary fat content on amino acid digestibility in young pigs. Journal of Animal Science 72, 1737-1743.

McCullough H 1967. The determination of ammonia in whole blood by direct colorimetric method. Clinica Chimica Acta 17, 297-304.

Mosenthin R, Sauer WC and Ahrens F 1994. Dietary pectin: effect on ileal and faecal amino acid digestibility and exocrine pancreatic secretion in growing pigs. Journal of Nutrition 124, 1222-1229.

Mosenthin R, Sauer WC, Ahrens F, De Lange CFM and Bornholdt U 1992. Effect of dietary supplements of propionic acid, siliceous earth or a combination of these on the energy, protein and amino acid digestibilities and concentrations of microbial metabolites in the digestive tract of growing pigs. Animal Feed Science and Technology 37, 245-255.

Mroz Z, Jongbloed AW, Partanen KH, Vreman K, Kemme PA and Kogut J 2000. The effects of calcium benzoate in diets with or without organic acids on dietary buffering capacity, apparent digestibility, retention of nutrients, and manure characteristics in swine. Journal of Animal Science 78, 2622-2632.

Partanen $\mathrm{K}$ and Jalava T 2005. Effects of some organic acids and salts on microbial fermentation in the digestive tract of piglets estimated using an in vitro gas production technique. Agricultural and Food Science 14, 311-324.

Partanen $\mathrm{K}$, Jalava $\mathrm{T}$, Valaja J, Perttilä $\mathrm{S}$, Siljander Rasi $\mathrm{H}$ and Lindeberg $\mathrm{H}$ 2001. Effect of dietary carbadox or formic acid and fibre level on ileal and faecal nutrient digestibility and microbial metabolite concentrations in ileal digesta of the pig. Animal Feed Science and Technology 93, 137-155. 
Partanen KH and Mroz Z 1999. Organic acids for performance enhancement in pig diets. Nutrition Research Reviews 12, 117-145.

Partanen K, Valaja J, Siljander-Rasi $H$, Jalava $T$, Toivonen $V$ and Järvimäki S 1998. Effect of fibre content on ileal digestion of amino acids in wet barley distiller's feed. Effect of fibre content on ileal digestion of amino acids in wet barley distiller's feed. In Book of Abstracts of the 49th Annual Meeting of the European Association for Animal Production (ed. JAM Van Arendonk), p. 269. Wageningen Pers, Wageningen.

Pond WG, Pond KR, Ellis WC and Matis JH 1986. Markers for estimating digesta flow in pigs and the effects of dietary fiber. Journal of Animal Science 63, 1140-1149.

Ravindran V and Kornegay ET 1993. Acidification of weaner pig diets: a review. Journal of the Science of Food and Agriculture 62, 313-322.

Robertson JB and Van Soest PJ 1981. The detergent system of analysis and its application to human foods. In The analysis of dietary fibre in foods (ed. WPT James and 0 Theander), pp. 123-158. Marcel Dekker, New York.

Roth FX, Eckel B, Kirchgessner M and Eidelsburger U 1992. Influence of formic acid on pH-value, dry matter content, concentrations of volatile fatty acids and lactic acid in the gastrointestinal tract. 3. Investigations about the nutritive efficacy of organic acids in the rearing of piglets. Journal of Animal Physiology and Animal Nutrition 67, 148-156.

Sauer WC, Mosenthin R, Ahrens F and Den Hartog LA 1991. The effect of source of fiber on ileal and fecal amino acid digestibility and bacterial nitrogen excretion in growing pigs. Journal of Animal Science 69, 4070-4077.

Schulze H, Van Leeuwen P, Verstegen MWA, Huisman J, Souffrant WB and Ahrens F 1994. Effect of level of dietary neutral detergent fiber on ileal apparent digestibility and ileal nitrogen losses in pigs. Journal of Animal Science 72, 2362-2368.

Statistical Analysis Systems Institute 1999. OnlineDoc, version eight. SAS Institute Inc., Cary, NC. Available on internet: http://v8doc.sas.com/sashtml/
Stein HH, Trottier NL, Bellaver C and Easter RA 1999. The effect of feeding level and physiological status on total fluw and amino acid composition of endogenous protein at the distal ileaum in swine. Journal of Animal Science 77, 1180-1187.

Tuori M, Kaustell K, Valaja J, Aimonen E, Saarisalo E and Huhtanen P (1996). [Feed tables and feeding recommendations - ruminants, pigs, poultry, fur animals, horses.] Yliopistopaino, Helsinki

Udén P, Colucci PE and Van Soest PJ 1980. Investigation of chromium, cerium and cobalt as digesta flow markers in rate of passage studies. Journal of the Science of Food and Agriculture 31, 625-632.

Van Kleef DJ, Deuring K and Van Leeuwen P 1994. A new method of faeces collection in the pig. Laboratory Animals 28, 78-79.

Van Leeuwen P, Van Kleef DJ, Van Kempen GJM, Huisman J and Verstegen MWA 1991. The post-valve T-caecum cannulation technique in pigs applicated to determine the digestibility of amino acid in maize, groundnut and sunflower meal. Journal of Animal Physiology and Animal Nutrition 65, 183-193.

Van Soest PJ, Robertson JB and Lewis BA 1991. Methods of dietary fiber, neutral detergent fiber, and nonstarch polysaccharides in relation to animal nutrition. Journal of Dairy Science 74, 3583-3597.

Wenk C 2001. The role of dietary fibre in the digestive physiology of the pig. Animal Feed Science and Technology 90, 21-33.

Williams CH, David D and lismaa 0 1962. The determination of chromic oxide in faeces samples by atomic absorption spectrometry. Journal of Agricultural Science, Cambridge 59, 381-385.

Wünsche J, Völker T, Souffrant WB and Borgman E 1991. Assessment of the bacteria bacterial $\mathrm{N}$ proportions in faeces and differently obtained ileal digesta of pigs. Archives of Animal Nutrition 41, 703-716.

Zinn RA and Owens FN 1986. A rapid procedure for purine measurement and its use for estimating net ruminal protein synthesis. Canadian Journal of Animal Science 66, 157-166. 